\title{
Structural control on kimberlite genesis and crustal emplacement within South Africa and the Kaapvaal Craton during the Cretaceous
}

Friese, A.E.W.

Geophysical Services Dept., Anglo American Corporation, PO Box 61587, Marshalltown 2107, Johannesburg, RSA

There has been considerable debate worldwide about the process(es) responsible for alkaline magmatism, including kimberlites and related rocks. Plume models are supported by apparent hot-spot tracks (e.g. Morgan, 1972; Gass et al., 1978; Crough et al., 1980) and extensional models are supported by lineament analysis or timing of alkaline volcanism in relation to extensional tectonics (e.g. Sykes, 1978; Bailey, 1993: White et al., 1995). Though the issue is contentious, lithospheric sources for the kimberlites, significant numbers of ages that do not fit apparent tracks, and uncertainty as to the location of plumes relative to the Kaapvaal Craton in the Cretaceous (e.g. O'Conner \& Duncan, 1990) are not supportive of simple plume models for the kimberlitic magmatism in South Africa (Skinner et al., 1995; Smith \& Barton, 1995). In addition, there is little evidence for the contention that Cretaceous kimberlites in South Africa occur in association with major continental rift systems, because of the absence of rock types (e.g. carbonatites and other alkaline volcanics) normally found within such an extensional setting. The attenuation and thinning of the lithosphere that would accompany rifting processes could be expected to rule out the formation of diamondiferous kimberlitic magmas within rift systems (Mitchell, 1986). Furthermore, major Archaean lineaments within the Kaapvaal Craton which could be construed as rifts, were seen until recently to have had no influence on the distribution of Phanerozoic kimberlites (Skinner et al., 1992). However, in a tectonic reconstruction and interpretation of the Kaapvaal Craton, Friese et al. (1995) and Friese (in prep.) identified several major, possibly trans-lithospheric Archaean terrane boundaries (suture zones) within the craton and demonstrated their repeated control as tectonic relaystructures over the tectono-sedimentary and magmatic evolution of the Kaapvaal Craton since the late Archaean to present time.

Smith et al. (1993) and Smith \& Barton (1995) compiled emplacement ages of Phanerozoic alkaline magmas on the Kaapvaal Craton and concluded that a) ages range from $245 \mathrm{Ma}$ to about $35 \mathrm{Ma}$, with all known Group II kimberlites being older than about $114 \mathrm{Ma}$, and younger kimberlites and related rocks being all of Group I affinity; and b) two peaks of eruptive activity occur at 120 to $118 \mathrm{Ma}$ (Group II) and $86 \mathrm{Ma}$ (Group I). The authors suggested correlations of the main eruptive events with other geodynamic features, as opposed to plume or extensional models. They pointed out that the main Group II event could be a response to lithospheric stresses induced by initial opening of the Atlantic Ocean, and/or a change in the direction of absolute motion of the African plate at that time. The main Group I eruptive event occurred at a time of particularly rapid motion of the African plate. Isotopic data constrain the sources for the alkaline magmas and kimberlites to lie within the subcontinental lithosphere, and not within an asthenospheric plume that the African plate may have migrated over. The source regions of kimberlite production changed in time, with the Group I source being tapped only sporadically prior to $114 \mathrm{Ma}$, and the ancient enriched Group II source being completely eliminated as a kimberlite source after $114 \mathrm{Ma}$. This may fit a model of extensional melting in response to Gondwana fragmentation (Smith \& Barton, 1995). In recent years, research regarding neotectonic activity in Southern Africa has revealed, that there is a striking match between the tectonic fabric of the southeast Atlantic and southwest Indian oceans and the tectonic fabric of the African subcontinent (e.g. Andreoli et al. 1996). It is evident that a number of major oceanic transform faults or fracture zones continue into on-shelf and on-shore joints/faults of the South African continent. In addition, neotectonic activity in Southern Africa has been analysed in terms of known stress fields and it is clear today, that the African plate south of the equator appears divided in two zones of compressive stress orientation: one zone of predominant NNE-directed trends which corresponds to the East African Rift system, and a second zone in southern Africa, but including the southwest Indian and southeast Atlantic oceans, characterized by NW-WNW trends (Zoback et al., 1992; Andreoli et al., 1996). Most of South Africa, Namibia and the floor of the adjacent oceans is dominated by this pervasive, NW: WNW-trending, horizontal compressive stress field of deep-seated, undetermined origin for which the term Wegener StresS Anomaly (WSA) was proposed (Andreoli et al., 1996). The WSA appears to have existed already in the Jurassic, before the break-up of Gondwana, which is indicated by the orientation of major Jurassic dyke swarms in South America, South Africa, Botswana and Zimbabwe, and persisted during the south Atlantic break-up phase in the Cretaceous (indicated by WNW-trending Cretaceous kimberlite dykes in Lesotho) until today. Off-shore fault zones caused by the WSA include the WNW-trending, so-called Ceres-Prince Edward Fracture Zone (CPEFZ) and Trans Indian Fracture Zone (TIFZ) in the southwest Indian Ocean. Short periods of waning during the Late Cretaceous caused the stress field to be dominated by NE-directed ridge push, which led to strike-slip along the Falkland-Agulhas Fracture Zone and the formation of the Cape-Tzaneen Fracture Zone (CTFZ), the on-shore continuation within the South African continent of the False Bay Fracture Zone (Andreoli et al., 1996). (Fig. 1). It is now proposed, that the Gondwana fragmentation with the opening of the Atlantic and Indian oceans and related tectonics of the CPEFZ/TIFZ, peaked between the Mid-Cretaceous and the Eocen, and provided, in conjunction with the CTFZ and other related NE-striking fracture zones, the structural setting and control, that may have triggered the broadly coeval cycle(s) of post-Karoo magmatism in southern Africa (Bailey, 1992; Smith \& Barton, 1995; Andreoli et al., 1996).

With regard to the distribution and orientation of Cretaceous kimberlite pipes and dykes within South Africa and the Kaapvaal Craton, some fundamental conclusions can be drawn: The majority of kimberlite pipe clusters occur at the intersection of NW/SE- and NE/SW-trending fractures belonging to the postKaroo-recent CPEFZ/TIFZ and CTFZ, respectively. Kimberlite dykes occupy both sets of fracture zones. Some kimberlite pipe clusters occur at the intersection of these Phanerozoic fractures zones with major 
Archaean terrane boundaries or Archaean crustal fault systems within the Kaapvaal Craton (Fig. 1). Kimberlite pipes (e.g. Saaiplaas pipe) encountered in the Free State Goldfield occur at the intersection of WNW-ESE trending kimberlite dykes and major pre-existing Platberg-age faults (e.g. De Bron Fault). The absence of any major, deep-seated Archaean lineaments within the area of the Free State Goldfield indicates, that the WNW-trending fissure- and fracture-system (TIFZ), that formed since post-Karoo time and has been invaded by Cretaceous kimberlite magmas, is deep-seated and functioned as primary conduits for these magmas. The non-translithospheric Archaean crustal fault system experienced minor reactivation in Cretaceous time and was partially utilized as pathways for the ascending kimberlitic magmas, particularly where transected by the CPEFZ/TIFZ.

World-wide observations and the above documented findings from the Kaapvaal Craton have clearly shown, that in most cases the sites of intracontinental anorogenic alkaline magmatic activity is governed by pre-existing lines of intracrustal weakness (e.g. Dawson, 1970; Sykes, 1978; Bailey, 1993; White et al., 1995), and not simply the rise of mantle plumes (Fitton \& Dunlop, 1985). Cooper (1990) proposed that the occurrence of mantle plumes and continental hot spots seem to be a consequence (Hamilton, 1988) rather than the cause of lithospheric extension (Burke \& Dewey, 1973). Support for this interpretation is provided by the lower-order periodicity of volcanism in continental rifts (Baker et al., 1972) because constraints imposed by heat conduction make episodic behaviour in mantle diapirs unlikely (Gass, 1975). Accepting tectonic activity within the lithosphere to be the controlling factor for these mantle processes, Bailey (1993) questioned, that either melts are omnipresent near the base of the lithosphere and simply await for channel openings to appear, or that melt generation is triggered by stress release in the overlying lithosphere. Since melt generation cannot be initiated by local heating, and the fact, that episodic magmatism along pre-existing zones of crustal weakness is widely scattered across the African plate during the same time interval, led Bailey (1993) to the conclusion, that the crucial factor in magma genesis is the focussing of fluid release from the deep mantle, whenever old lesions are re-opened through the lithosphere (decompressional melting). This indicates minimal inertia in the magma generating systems which is revealed in the ready response to plate-wide triggering (and shut-down) mechanisms. In summary, magmatology, the lithospheric regime, episodicity and repetition of magmatic activity, thus form a coherent pattern consistent with periodic reactivation of the plate by external forces (Bailey, 1993).

Regarding Cretaceous alkaline magmatic activity in South Africa, it can be concluded on the basis of the above spatial, temporal and petrogenetic considerations, that magmatism during this period was not controlled by deep mantle plumes impinging on the base of the lithosphere but rather by craton-wide operating lithospheric processes, triggered by Gondwana fragmentation. Although the existence of deeply penetrating faults within the continental lithosphere was largely doubted in the past, deep crustal seismic studies have now documented the presence of trans-lithospheric faults. As such, the main regional controls over the genesis and the emplacement of alkaline and kimberlitic magmatism involve deep fractures, faults or shear zones in the continental crust that transverse deep into the lithosphere and either form or experience reactivation in an extensional setting, hence causing decompressional melting in the upper mantle and allowing the magmatism to penetrate to surface through the crust. Such deep-seated structures within the continental lithosphere of South Africa are represented by Archaean suture zones identified within the Kaapvaal Craton, as well as by the post-Karoo-recent fracture system, that formed in response to Gondwana fragmentation. A similar association between alkaline magmatism and the extensional reactivation of deep-seated, old continental structures and/or on-land extensions of oceanic transform fracture zones, has been reported worldwide (e.g. Marsh, 1973; Williams \& Williams, 1977; Sykes, 1978; Stracke et al., 1978; Haggerty, 1992).

Andreoli, M.A.G.; Doucouré, M.; Van Bever Donker, J.; Brandt, D. \& Andersen, N.J.B., 1996. Neotectonics of southern Africa - a review. Africa Geoscience Review 3/1, 1-16.

Bailey, D.K., 1993. Petrogenetic implications of the timing of alkaline, carbonatite, and kimberlite igneous activity in Africa. S. Afr. J. Geol., 96/3, 67-74. Baker, B.H.; Mohr, P.A. \& Williams, L.A.J., 1972. Geology of the eastern rift system of Africa. Spec. Pap. Geol. Soc. Am.,136. 136-142. Burke, K. \& Dewey, J.F., 1973. Plume generated triple junctions: key indicators in applying plate tectonics to older rocks. J. Geol., 81 , $406-433$. Cooper, M.R., 1990. Tectonic cycles in southern Africa. Earth-Science Reviews, 28, $321-364$.

Crough, S.T.; Morgan, W.J.; \& Hargraves, R.B., 1980. Kimberlites: their relation to mantle hotspots. Earth Planet. Sci. Lett., 50, $260-274$

Dawson, J.B., 1970. The structural setting of African kimberlite magmatism. In: Clifford, T.N. \& Gass, K. (eds.), African Magmatism and tectonics. Oliver \& Boyd Edinburgh, 321-335.

Fitton, J.G. \& Dunlop, H.M., 1985. The Cameroon line, West Africa, and its bearing on the origin of oceanic and continental alkali basalt. Earth Planet. Sci. Lett., $72,23-38$.

Friese, A.E.W.; Charlesworth, E.G. \& McCarthy, T.S., 1995. Tectonic processes within the Kaapvaal Craton during the Kibaran (Grenville0 Orogeny: Structural, geophysical and isotopic constraints from the Witwatersrand Basin and environs. Inform. Circ. Econ. Geol. Res., Univ. Witwatersrand, Johannesburg, $292,67 \mathrm{pp}$.

Friese, A.E.W. (in prep.). The tectono-sedimentary evolution of the southern Free State Goldfield within the Witwatersrand Basin, with implications for

the development of the Kaapvaal Craton, South Africa. Ph.D. dissertation (unpubl.) Univ. Witwatersrand, Johannesburg.
Gass, I.G.. 1975. Tectonic and magmatic evolution of theAfro-Arabian dome. In: Clifford, T.N. \& Gass, I.G. (eds.), African Magmatism and Tectonics, Oliver \& Boyd, Ėdinburgh, 285-300.

Gass, I.G.; Chapman, D.S.; Pollack, H.N. \& Thorpe, R.S. (1978). Geological and geophysical parameters of mid plate volcanism. Philos. Trans. R. Soc. London, 288A, $581-597$

Haggerty, S.E.. 1992. Diamonds in West Africa: Tectonic setting and diamond productivity. Russ. Geol. Geophys., 33, 35-49

Hamiton, W..B. 1988. Plate tectonics and island arcs. Bull. Geol. Soc. Am., 100, 1503-1527.

Marsh, J.S., 1973. Relationships between transform directions and alkaline igneous rock lineaments in Africa and S. America. Earth Planet. Sci. Lett., 18

Mitchell, R.H., 1986. Kimberlites: Mineralogy. Geochemistry and Petrology. Plenum Publ. Corp. New York, 422 p.

O'Conner, J.M. \& Duncan, R.A., 1990. Evolution of Walvis Ridge - Rio Grande Rise hot spot system: indicators for African \& South American plate

motions over plumes. J. Geophys. Res., 95/B11, 17475-17502. \& Hatton, C.J., 1992. The distribution and tectonic setting of South African kimberlites Russ. Geol. Geophys., 33, 26-31.

Skinner, E.M.W.; Smith, C.B.; Viljoen, K.S. \& Clark, T.C., 1995. The petrography, tectonic setting and emplacement ages of kimberlites in the Southwestern border region of the Kaapvaal Craton. Prieska area, South Africa. Proceedings of the $5^{\text {th }}$ Intern. Kimberlite Conference, Novosibirsk, Russia Smith, C.B.; Barton, E.S. \& Bristow, J.W., 1993. Kimberlite emplacement ages in Southern Africa - a complex history. Ext. Abstr., 16 ${ }^{\text {th }}$ International Colloquium Of African Geology, Ezulwini, Swaziland, 2, 329-330.

Smith, C.B. \& Barton, E.S., 1995. The timing of kimberlite emplacement in southern Africa. Ext. Abstr., Geocongress '95, Geol. Soc. S. Afr., Johannesburg. Stracke, K.J.; Ferguson, J. \& Black, L.P., 1978. Structural setting of kimberlites in South Eastern Australia. In: F.R. Boyd \& H.O.A. Meyer (eds.) Diamonds and Diatremes. Am Geophys. Union, $71-91$

Sykes, L.R. (1978): Intraplate seismicity, reactivation of pre-existing zones of weakness, alkaline magmatism, and other tectonism postdating continental fragmentation. Reviews Geophys. Space Phys. $16,621-688$

White, S.H.; de Boorder, H. \& Smith, C.B., 1995. Structur. controls of kimberlite and lamproite emplacement. J. Geoch. Expl., 53, 245-264

Williams, H.R. \& Williams, R.A., 1977. Kimberlites and plate tectonics in West Africa. Nature, 270, $507-508$.

Zoback, M.L., 1992. First-and second-order patterns of stress in the lithosphere:the world stress map. J. Geophys. Res., 97/B8,11703-11728. 

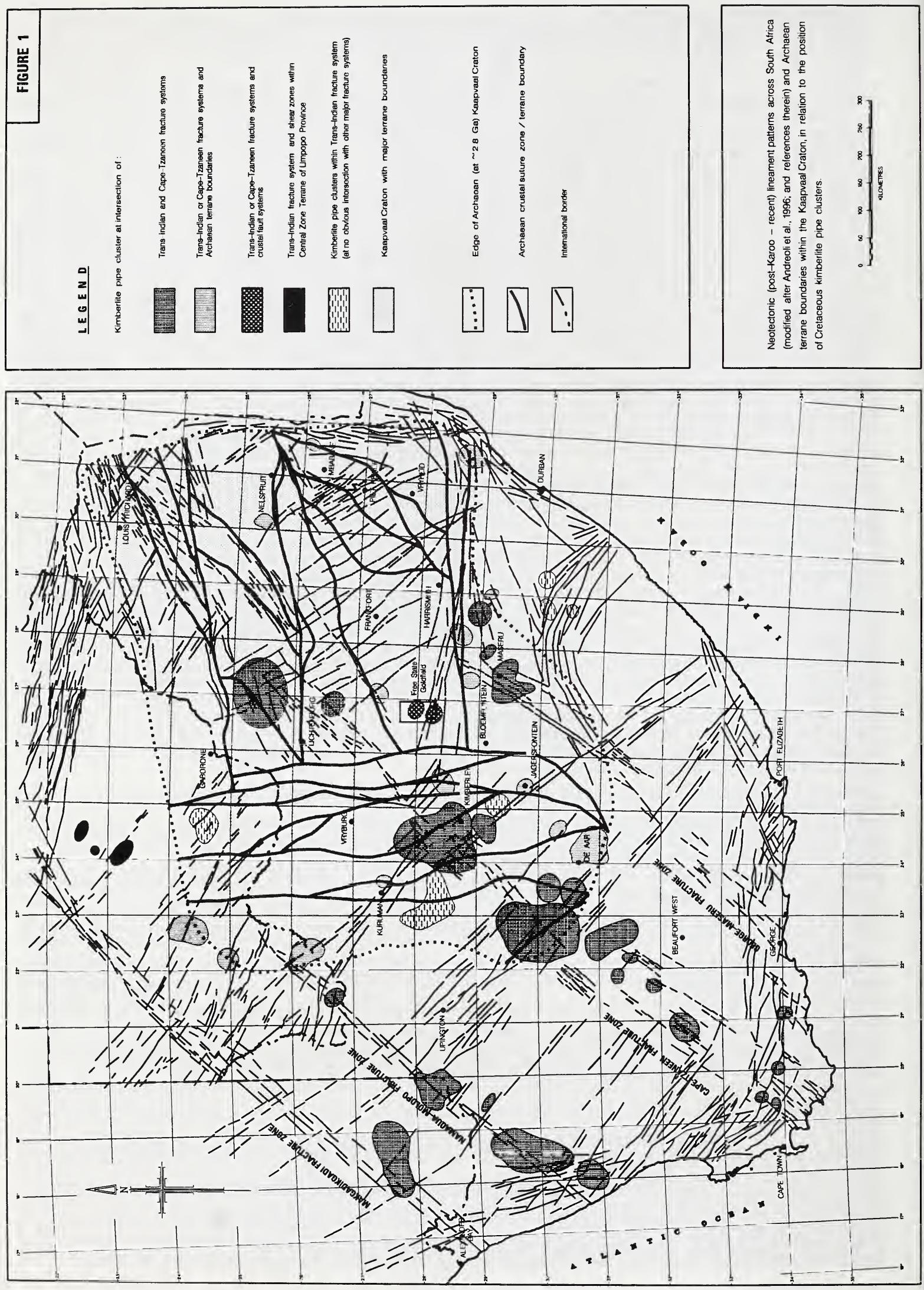